\title{
Conservation and diversity of Palaearctic grasslands - Editorial to the 5th EDGG special issue in Hacquetia
}

\author{
*Orsolya Valkó ${ }^{1}$, Rocco Labadessa², Salza Palpurina ${ }^{3}$, Sabina Burrascano ${ }^{4}$, \\ Atushi Ushimaru ${ }^{5}$, Stephen Venn ${ }^{6,7}$
}

Key words: biodiversity, conservation, grassland, Palaearctic, steppe, syntaxonomy.

Ključne besede: biotska pestrost, varstvo, travišča, Palearktika, stepa, sintaksonomija.

Received: 26. 6. 2019

Accepted: 26. 6. 2019

\begin{abstract}
Palaearctic grasslands are diverse and dynamic ecosystems that are in the focus of ecology, conservation biology and agronomy. This special issue is dedicated to the biodiversity and conservation issues of Palaearctic grasslands and was initiated by the Eurasian Dry Grassland Group members attending the 14th Eurasian Dry Grassland Conference (EDGC) at Sulmona, Italy in 2018. The papers in this special issue cover a wide range of grassland ecosystems from mountain dry grasslands to lowland loess grasslands, feathergrass steppes and wet grasslands, and focus on the biodiversity values and conservation issues of Palaearctic grasslands. We believe that this compilation will contribute to a better understanding of the ecology of grasslands and support their more effective conservation.

\section{Izvleček}

Palearktična travišča so raznoliki in dinamični ekosistemi, ki so v ekologiji, naravovarstveni biologiji in agronomiji v središču raziskav. $V$ posebni številki namenjeni biotski pestrosti in naravovarstvu, ki so jo sestavili člani Skupine za evrazijska suha travišča na 14. konferenci o evrazijskih suhih traviščih (EDGC) v Sulmoni v Italiji leta 2018. Članki v tej posebni številki obravnavajo širok spekter tem o travniških ekosistemih - od gorskih suhih travišč do nižinskih travišč na lesu, stepskih in vlažnih travišč z bodalicami. Osredotočili smo se na pomen pestrosti in naravovarstva palearktičnih travišč. Menimo, da bo ta izbor člankov doprinesel $\mathrm{k}$ boljšemu razumevanju ekologije travišč in podprl njihovo bolj uspešno varovanje.
\end{abstract}

1 MTA-DE Lendület Seed Ecology Research Group, Egyetem sqr. 1, H-4032, Debrecen, Hungary. E-mail: valkoorsi@gmail.com *Corresponding author

2 Association Centro Studi de Romita, Via G. Postiglione 9, c/o Filippo D’Erasmo, 70126 Bari, Italy. E-mail: rocco.labadessa@gmail.com

3 Institute of Biodiversity and Ecosystem Research, Bulgarian Academy of Sciences, Sofia, 1113, Bulgaria. E-mail: salza.palpurina@gmail.com

4 Department of Environmental Biology, Sapienza University of Rome, Piazzale Aldo Moro 5, 00185 Rome, Italy. E-mail: sabina.burrascano@uniroma1.it

5 Graduate School of Human Development and Environment, Kobe University, Tsurukabuto, Nada-ku 3-11, Kobe City, Hyogo, 657-8501, Japan. E-mail: ushimaru8@gmail.com

6 Ecosystems and Environment Research Programme, Faculty of Biological and Environmental Sciences, University of Helsinki, P.O. Box 65 (Viikinkaari 2a), 00014, Finland. E-mail: stephen.venn@helsinki.fi

7 Department of Architecture, Aalto University, P. O. Box 16500 (Miestentie 3), 00076 Aalto, Finland 


\section{Introduction and motivation of the special feature}

This special issue complements a series of special volumes devoted to Palaearctic grasslands (including Habel et al. 2013, Janišová et al. 2014, Apostolova et al. 2014, Dengler et al. 2014, Carboni et al. 2015, Ruprecht et al. 2015, Török et al. 2016, Becker et al. 2016, Valkó et al. 2016c, 2018, Deák et al. 2017, 2018), edited on behalf of the Eurasian Dry Grassland Group (EDGG, http://www. edgg.org). The present special feature was initiated by the EDGG subsequent to the 14th Eurasian Dry Grassland Conference (EDGC) at Sulmona, Italy in June 2018 (Burrascano et al. 2018, Dengler et al. 2019a).

\section{Contributions of the special issue}

This special issue consists of five contributions, from Switzerland (Dengler et al. 2019b), Hungary (Deák et al. 2019, Tóth et al. 2019), Greece (Tsiobani et al. 2019), and Ukraine (Polchaninova et al. 2019). These studies cover a wide range of grassland ecosystems from mountain dry grasslands to lowland loess grasslands, feather- grass steppes and wet grasslands, and focus on the biodiversity value and conservation issues of Palaearctic grasslands. This special issue also contains a report on the activities of the Eurasian Dry Grassland Group in 20182019 (Dengler et al. 2019a)

Dengler et al. (2019b) studied the syntaxonomy and ecology of dry grasslands in the upper Rhone valley, Valais, Switzerland. They studied the vegetation of these xerothermic grasslands at spatial scales ranging from 0.0001 to $100 \mathrm{~m}^{2}$ according to the GrassPlot methodology (Dengler et al. 2016) and found that the species-area relationships followed a power function. Among the 217 plant species found in this study, the most noteworthy ones were Festuca pallens, Astragalus excapus, Hieracium velutinum, Ceratodon conicus and Cladonia novochlorophaea, which had no or only very few records in the region previously. The authors confirmed that the Stipo pulcherrimae-Festucetalia pallentis also occurs in the Swiss inner-alpine valleys, next to typical Festucetalia valesiacae communities. Therefore, the paper extends the known distribution range of the Stipo pulcherrimae-Festucetalia pallentis to the southwest. The authors showed that the "Stipo-Poion" of Swiss authors consists of two floristically and ecologically distinct units belonging to the Stipo pulcherrimae-Festucetalia pallentis and the Festucetalia valesiacae orders.

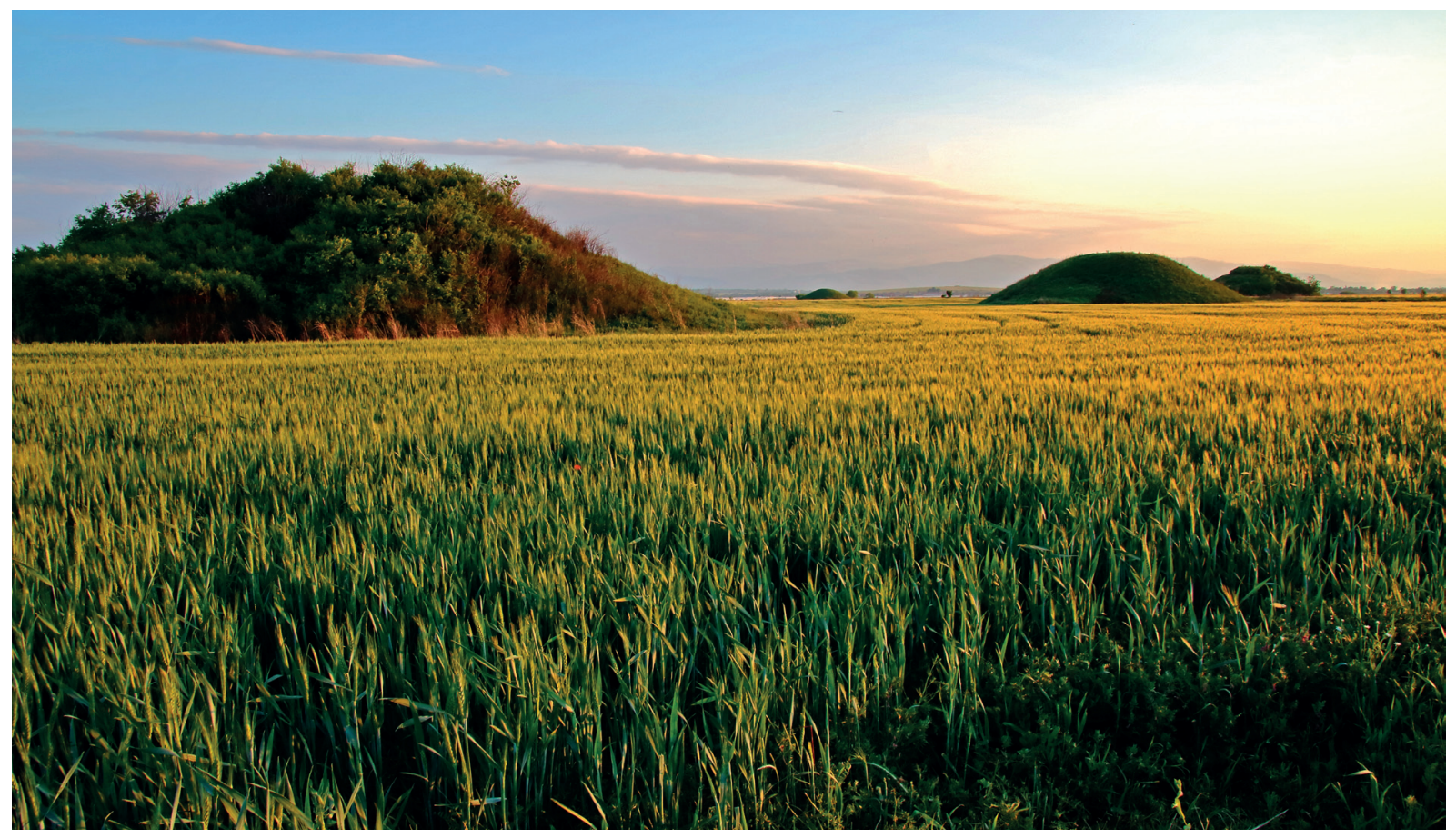

Figure 1: Kurgans hold the last remnants of dry grasslands in the intensively used agricultural landscape in the Maritsa river valley, South Bulgaria. Photo by Balázs Deák.

Slika 1: Na gomilah najdemo še zadnje ostanke suhih travišč v intenzivno obdelani kmetijski krajini v dolini reke Maritsa v južni Bolgariji. Foto Balázs Deák. 
A new database on the conservation values associated with the ancient steppic burial mounds, is introduced in the paper of Deák et al. (2019). Kurgans are ancient burial mounds built by nomadic steppic cultures dating back to the Bronze Age. There are approximately half a million kurgans in the Eurasian steppe and forest steppe zones (Deák et al. 2016a). These historical monuments also hold outstanding conservation value, as they often retain the last remnants of dry grasslands in otherwise extensively agricultural landscapes (Deák et al. 2016b, SudnikWójcikowska et al. 2011, Tóth et al. 2019; Figure 1). Despite their cultural, historical and nature conservational importance, databases on the distribution, attributes and vegetation of kurgans, is lacking in most parts of Eurasia. The Eurasian Kurgan Database aims at providing an open access platform for recording, collecting and sharing data on the distribution, land-cover, land-use and threatfactors of the mounds. The paper describes the structure and data management policy of the database and also calls for contributions from all regions of Eurasia.

In their case study, Tóth et al. (2019) show the importance of kurgans in nature conservation. They studied the geomorphology, soil parameters, vegetation and arthropod assemblages of a twin kurgan complex called the Zsolca mounds in Northeastern Hungary. These two kurgans cover a total area of only 0.8 hectares and are situated in an intensively used agricultural landscape, but still harbour several plant (e.g. Echium russicum, Linum flavum, Phlomis tuberosa, Pulsatilla grandis) and animal species (e.g. Carabus cancellatus, C. violaceus, Dorcus parallelipipedus) of conservation interest (Figure 2). The kurgans harboured dry and warm habitats on the southern slopes, while the northern slopes had higher biodiversity, due to the balanced water supplies. The authors found that both microhabitats had different assemblages of ground-dwelling invertebrates. The negative effects of the surrounding arable land were detectable in a three-metre wide zone next to the edge of the kurgan, where the naturalness of the vegetation was lower, and the frequency of weeds, ruderal species and crop plants, was higher than in the central zone. The study highlights that without specific measures to avoid the degradation of the kurgans through invasion by weeds, their assemblages are likely to decline and eventually be lost, with a major impact on regional biodiversity.

Tsiobani et al. (2019) studied the diet selection of water buffalos in relation to the seasonal variability of wet grassland vegetation in Northern Greece. They recorded the plant species composition monthly in wet grasslands and the species consumed by the buffalos. Their observations revealed that buffalos preferred forbs, legumes and grasses and only rarely chose trees and shrubs. The diet of the buffalos was the most diverse in spring. There was a

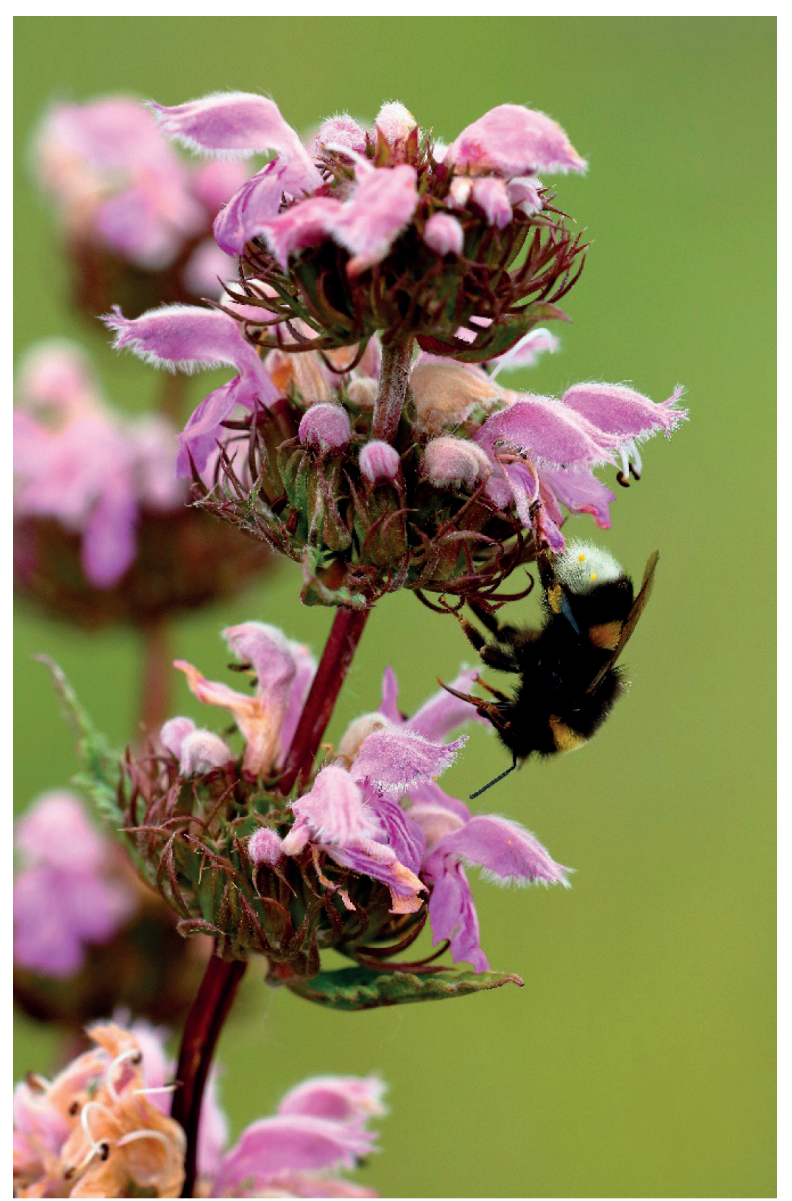

Figure 2: Phlomis tuberosa, a typical species of dry grasslands on kurgans. Photo by Balázs Deák.

Slika 2: Phlomis tuberosa, značilna vrsta suhih travišč na gomilah. Foto Balázs Deák.

strong correlation between the abundance of plant species in the grassland vegetation and those that were consumed by animals. Even though the animals tested a great number of available species (66 out of 104 species), there were only ten species which they consumed constantly, in all the seasons. The findings have implications for rangeland management of wet grasslands.

Polchaninova et al. (2019) studied the effect of a highseverity fire on the cursorial arthropod assemblages and vegetation of Ukrainian steppes. Their sampling design enabled them to compare the pre-fire arthropod assemblages to the post-fire ones. They found that the living cover of vascular plants recovered within a year, and the burnt site was quickly recolonised by mobile arthropods from the unburnt surroundings. Spider assemblages recovered quickly, but the recovery of beetle assemblages was slower. After fire, there was a decrease in the abundance of herbivores and increased abundance of omnivore species. In the burnt area, the diversity of the arthropod 
assemblages, resulting from the patchiness of the vegetation cover, decreased considerably. The results suggest that abandonment of grazing in the steppe gully systems can increase the accumulation of biomass and thus the risk and frequency of fires in the future, which can have a fundamental impact on the steppic arthropod fauna.

\section{Acknowledgements}

We are grateful to all the authors for their contributions to this special issue and to the reviewers for their considerable input in improving the manuscripts. We would like to thank the support of Urban Šilc, Editor-in-Chief of Hacquetia for supporting the current and past special features. Many thanks to Aiko Huckauf for professional linguistic editing and the courtesy of the Eurasian Dry Grassland Group for financial support. O.V. was funded by NKFI FK 124404 and NKFI KH 126476 grants, the Bolyai János Research Fellowship and the UNNKP-18-4DE-12 grant during manuscript preparation.

\section{References}

Apostolova, I., Dengler, J., Di Pietro, R., Gavilán, R. \& Tsiripidis, I. 2014: Dry grasslands of Southern Europe: Syntaxonomy, management and conservation. Hacquetia 13: 5-18.

Becker, T., Csecserits, A., Deák, B., Janišová, M., Sutcliffe, L. \& Wagner, V. 2016: Different approaches in grassland analysis - Editorial to the 11th EDGG Grassland Special Feature. Tuexenia 36: 287-291.

Burrascano, S., Ciaschetti, G., Vrahnakis, M. \& Dengler, J. 2018: Report on the 15thEurasian Grassland Conference in Sulmona, Italy. Palaearctic Grasslands 38: 12-17.

Carboni, M., Dengler, J., Mantilla-Contreras, J., Venn, S. \& Török, P. 2015: Conservation value, management and restoration of Europe's semi-natural open landscapes. Hacquetia 14: 5-17.

Deák, B., Tóthmérész, B., Valkó, O., Sudnik-Wóicikowska, B., Bragina, T.-M., Moysiyenko, I., Apostolova, I., Bykov, N., Dembicz, I. \& Török, P. 2016a: Cultural monuments and nature conservation: The role of kurgans in maintaining steppe vegetation. Biodiversity \& Conservation 25: 2473-2490.

Deák, B., Valkó, O., Török, P. \& Tóthmérész, B. 2016b: Factors threatening grassland specialist plants - A multi-proxy study on the vegetation of isolated grasslands. Biological Conservation 204: $255-262$.

Deák, B., Wagner, V., Csecserits, A. \& Becker, T. 2017: Vegetation and conservation of Central-European grasslands - Editorial to the 12th EDGG Special Feature. Tuexenia 37: 375-378.

Deák, B., Becker, T., Boch, S. \& Wagner, V. 2018: Conservation, management and restoration of semi-natural and natural grasslands in Central Europe - Editorial to the 13th EDGG Special Feature. Tuexenia 38: 305-310.
Deák, B., Tóth, C., Bede, Á., Apostolova, I., Bragina, T.M., Báthori, F. \& Bán, M. 2019: Eurasian Kurgan Database - a citizen science tool for conserving grasslands on historical sites. Hacquetia 18 (2): 185-193.

Dengler, J., Janišová, M., Török, P. \& Wellstein, C. 2014: Biodiversity of Palaearctic grasslands: a synthesis. Agriculture Ecosystems and Environment 182: 1-14.

Dengler, J., Boch, S., Filibeck, G., Chiarucci, A., Dembicz, I., Guarino, R., Henneberg, B., Janišová, M., Marcenò, C., (...) \& Biurrun, I. 2016: Assessing plant diversity and composition in grasslands across spatial scales: the standardised EDGG sampling methodology. Bulletin of the Eurasian Dry Grassland Group 32: 13-30.

Dengler, J., Aleksanyan, A., Ambarlı, D., Biurrun, I., Dembicz, I., Kuzemko, A., Török, P., Venn, S., \& Vrahnakis, M. 2019b: The Eurasian Dry Grassland Group (EDGG) in 2018-2019. Hacquetia 18 (2): 147-154.

Dengler, J., Widmer, S., Staubli, E., Babbi, M., Gehler, J., Hepenstrick, D., Bergamini, A., Billeter, R., Boch, S., Rohrer, S. \& Dembicz, I. 2019b: Dry grasslands of the central valleys of the Alps from a European perspective: the example of Ausserberg (Valais, Switzerland). Hacquetia 18 (2): 155-177.

Habel, J. C., Dengler, J., Janišová, M., Török, P., Wellstein, C. \& Wiezik, M. 2013: European grassland ecosystems: Threatened hotspots of biodiversity. Biodiversity \& Conservation 22: 2131-2138.

Janišová, M., Boch, S., Ruprecht, E., Reitalu, T. \& Becker, T. 2014: Continental dry grasslands from range margin to range centre - Editorial to the 9th Dry Grassland Special Feature. Tuexenia 34: 347-353.

Polchaninova, N., Savchenko, G., Ronkin, V., Drogvalenko, A. \& Putchkov, A. 2019: Summer fire in steppe habitats: long-term effects on vegetation and autumnal assemblages of cursorial arthropods. Hacquetia 18 (2): 213-231.

Ruprecht, E., Janišová, M., Sutcliffe, L., Boch, S. \& Becker, T. 2015: Dry grasslands of Central-Eastern and South-Eastern Europe shaped by environmental heterogeneity and human land use - Editorial to the 10th Dry Grassland Special Feature. Tuexenia 35: 321-328.

Sudnik-Wójcikowska, B., Moysiyenko, I., Zachwatowicz, M. \& Jabłońska, E. 2011: The value and need for protection of kurgan flora in the anthropogenic landscape of steppe zone in Ukraine. Plant Biosystems 145(3): 638-653.

Török, P., Wesche, K., Ambarlı, D., Kamp, J. \& Dengler, J. 2016: Step(pe) up! Raising the profile of the Palaearctic natural grasslands. Biodiversity \& Conservation 25: 2187-2195.

Tóth, Cs. A., Deák, B., Nyilas, I., Bertalan, L., Valkó, O. \& Novák, T. 2019: Iron age burial mounds as refugia for steppe specialist plants and invertebrates - case study from the Zsolca mounds (NE Hungary). Hacquetia 18 (2): 189-200.

Tsiobani, E. T., Yiakoulaki, M. D. \& Menexes, G. 2019: Seasonal variation in water buffaloes' diet grazing in wet grasslands in Northern Greece. Hacquetia 18 (2): 201-212.

Valkó, O., Zmihorski, M., Biurrun, I., Loos, J., Labadessa, R. \& Venn, S. 2016c: Ecology and conservation of steppes and semi-natural grasslands. Hacquetia 15: 5-14.

Valkó, O., Venn, S., Zmihorski, M., Biurrun, I., Labadessa, R. \& Loos, J. 2018: The challenge of abandonment for the sustainable management of Palaearctic natural and semi-natural grasslands. Hacquetia 17(1): 5-16. 